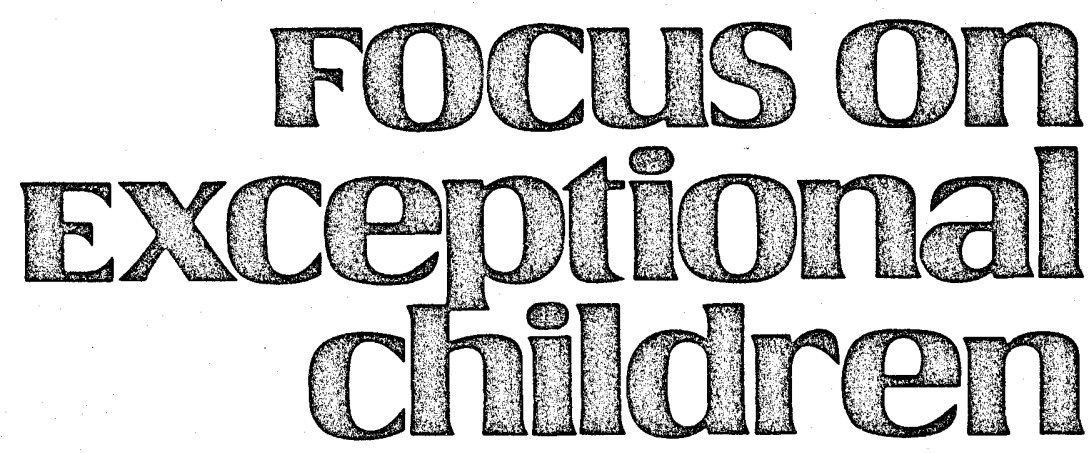

\title{
Social Maladjustment: \\ Definition, Identification, and Programming
}

David B. Center

After passage of the Education for All Handicapped Children Act (PL 94-142), a definition of serious emotional disturbance (SED) was adopted to aid implementing that legislation. The meaning of the social maladjustment (SMA) exclusion placed in the SED definition has puzzled educators and generated debate (Bower, 1982; Center, 1989b; Council for Children with Behavioral Disorders, 1987; Clarizio, 1987). Many states have dealt with this undefined exclusion by simply dropping SMA from their states' definition.

Recently, interest in the SMA exclusion has increased. Some see the SMA exclusion as a means of getting around the U.S. Supreme Court ruling in Honig v. Doe (January, 1988), which made expulsion more difficult. The most popular interpretation of SMA appears to be that it is any disorder in which the primary problem is related to social behavior (Center \& Eden, 1989). This broad interpretation is based largely upon the writings of Clarizio (1987), Kelly (1986), and Slenkovich (1983). I (Center, 1989b) have argued for a more limited interpretation of the SMA exclusion, and that interpretation will be the basis for this article.

\section{DEFINITION}

Implicit in the broad interpretation of SMA is the assumption that the PL 94-142 definition of SED is an exclusive definition limited to disorders in the affective domain (Center, 1989b). I argue that the definition is inclusive and applies to disorders of affective, cognitive, functional, or social behavior, or any combination of these. Students with problems of this nature would be eligible for special education services as long as their condition meets the criteria in the definition and they are not judged ineligible under the exclusion for SMA.

Dr: Center is with the Department of Special Education, Georgia State University. 
Several arguments support an inclusive interpretation of the SED definition (Center, 1989b).

1. The very presence of an exclusion suggests an inclusive definition. In an exclusive definition, there is no need for exclusions. The need for an exclusion can arise only in an inclusive definition.

2. Bower (1982), author of the definition that was adopted for the PL 94-142 definition of SED, takes an inclusive view. In fact, he states that he defined emotional disturbance in terms of children's social maladjustments and the exclusion renders the definition meaningless.

3. PL $94-142$ is a piece of educational legislation, and its focus is on educational handicaps. The research literature clearly indicates that behaviors resulting in an educational handicap are not limited to the affective domain. If anything, better evidence links academic and social behavior problems (Bower, 1981; Kupersmidt \& Patterson, 1987).

If 'the premise that the definition of SED is inclusive is accepted, the intent of the SMA exclusion clearly was not

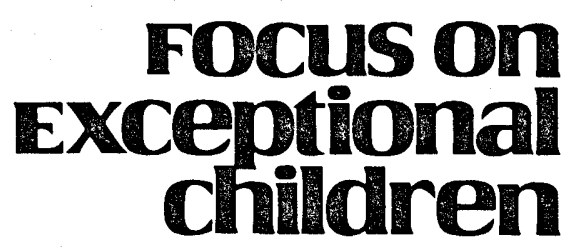

ISSN0015-511X

FOCUS ON EXCEPTIONAL CHILDREN (USPS 203-360) is published monthly except June, July, and August as a service to teachers, special educators, curriculum specialists, administrators, and those concerned with the special education of exceptional children. This publication is annotated and indexed by the ERIC Clearinghouse on Handicapped and Gifted Children for publication in the monthly Current Index to Journals in Education (CIJE) and the quarterly index, Exeptional Children Education Resources (ECER).. It is also available in microform from Xerox University Microfilms, Ann Arbor, MI. Subscription rates: Individual, \$27 per year; institutions, $\$ 36$ per year. Copyright (C) 1989, Love Publishing Company. All rights reserved. Reproduction in whole or part without written permission is prohibited. Printed in the United States of America. Second class postage is paid at Denver, Colorado. POSTMASTER: Send address changes to:

Love Publishing Company

Executive and Editorial Office

1777 South Bellaire Street

Denver, Colorado 80222

Telephone (303) 757-2579

Edward L. Meyen University of Kansas
Glenn A. Vergason Georgia State University

Richard J. Whelan

University of Kansas Medical Center

Stanley F. Love

Publisher
Carolyn Acheson

Senior Editor to exclude all disorders of social behavior. The intention was, however, to exclude some class of social behavior. The interpretation of SMA that I made (Center, 1989b) is that SMA is socialized delinquency, subcultural delinquency, socialized aggression as defined by Quay (1987), or conduct disorder (group type) as defined in DSM III-R (American Psychiatric Association, 1987). It seems reasonable to conclude that this was the group at which the SMA exclusion was directed. The reasoning is as follows:

1. Socialized aggression is believed to be an adaptive response to the environment (Quay, 1987). The behaviors associated with socialized aggression are accepted and supported by a specific subculture. In fact, the behaviors probably have been acquired in whole or in part from that subculture, much of which may be composed of peers. In short, the socialized aggressive (socially maladjusted) individual's problem behavior is probably attributable to inappropriate socialization, not inadequate socialization, as is likely the case with the under-socialized aggressive (conduct disorder).

2. Public school programs are not very well suited to correcting problems with a broad ecological basis such as social maladjustment.

3. Public schools, however, do make significant contributions to the socialization process. As an agent of socialization, they are better able to provide intervention programs for problems arising from inadequate socialization, which is probably the situation in conduct disorder.

In Figure 1 a hypothetical model of the relationship between the two major sources of socialization-adequacy of parenting and adequacy of the environment-has been mapped out along with predicted outcomes. The results of variable adequacy for each of these socialization influences is limited to three types of socialization experiences: deficient socialization, normal socialization, and deviant socialization. The outcomes are expressed in terms related to the social domain of behavior.

Influence of the home is represented by adequacy of parenting, which should be considered a dimensional construct ranging from poor to superior. Where any given family will fall along this dimension may change over time and will be influenced by a number of factors, including skill level, mental health, physical health, and family size, among others. Degree of adequacy also will be affected by the degree of adequacy of each individual parent and the extent of his or her presence or absence from the home. 


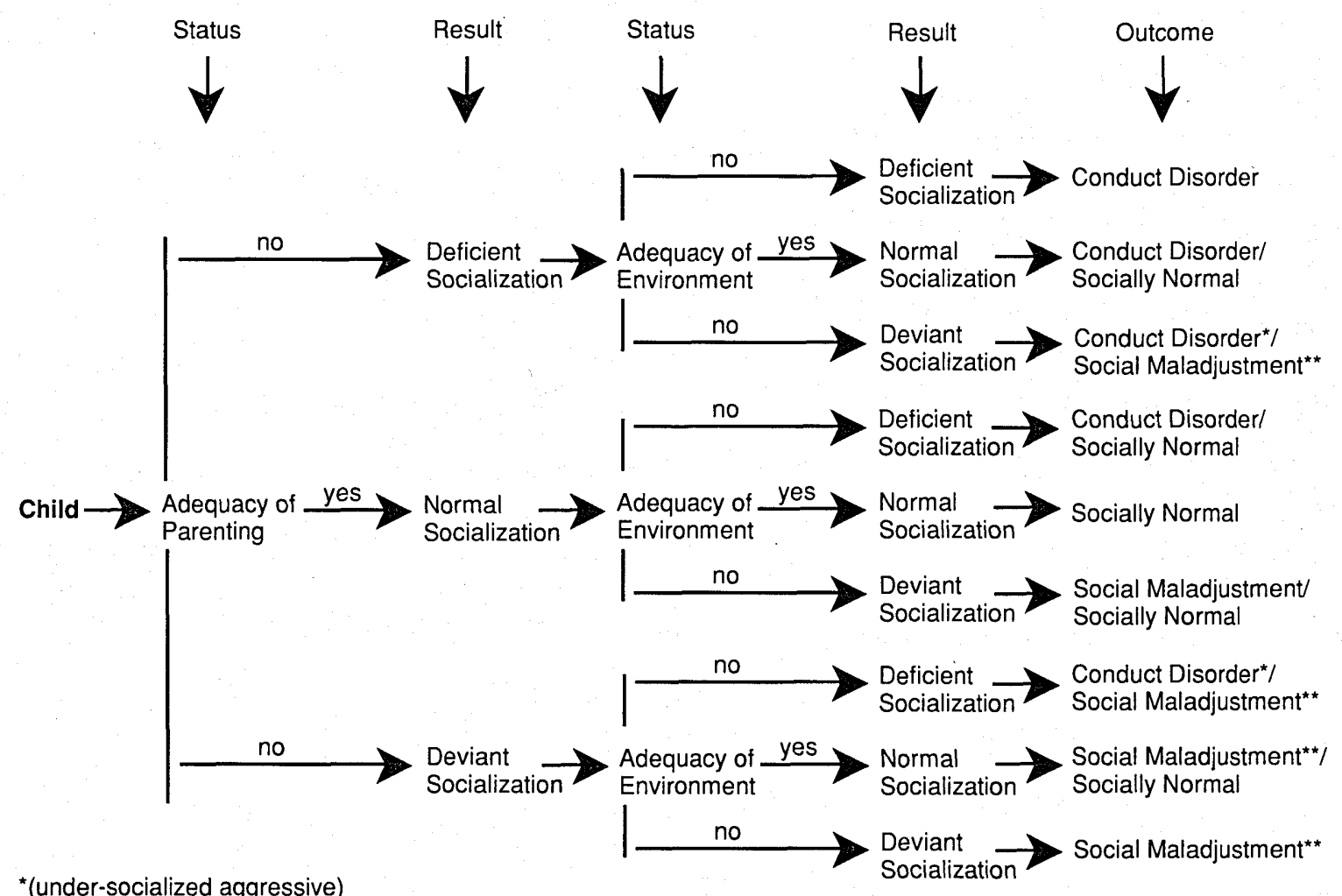

${ }^{\star}$ (under-socialized aggressive $)$
${ }^{*}($ (socialized aggressive $)$

FIGURE 1

Hypothetical Model of the Possible Relationship

Between Two Major Socialization Forces and Predicted Outcomes

Note. When either a normal or an abnormal outcome is predicted, it is hypothesized that biological predisposition will determine the outcome.

Influence of the community is represented by adequacy of the environment, which is likewise a dimensional construct and can vary from poor to superior. Degree of adequacy of the environment will be influenced by numerous variables including, but not limited to, the educational system, the peer group, and the community atmosphere. As with parenting, adequacy of the environment can vary and may be more or less adequate at different times.

There is a reason to suspect (Bleuler, 1974; Mednick, Schulsinger, \& Schulsinger, 1975; Mednick \& Hutchings, 1978; Thomps, Chess, \& Birch, 1968) that some children are variably predisposed, biologically, to be either vulnerable or resistant to deviancy-promoting environmental influences during development. This suspected biological predisposition is hypothesized to affect the child's subsequent response to the social environment, including both the home and the larger community. Therefore, in the predicted outcomes in Figure
1 , when either a normal or an abnormal outcome is predicted, it is hypothesized that the outcome is determined by the child's biological predisposition, or lack of it, for deviant social behavior.

There are variable degrees of adequacy of parenting and adequacy of environment, as mentioned. Biological predisposition also may be variable. Taking the variability of these three influences into account, it is hypothesized that positive outcomes will vary from marginal to excellent. Negative outcomes, it is hypothesized, will vary from mild to serious.

Children who experience deficient socialization are most susceptible to developing conduct disorder. Those who experience deviant socialization are most susceptible to developing social maladjustment. Deficient socialization in the home should make the child more vulnerable to deviant socialization by the broader environment when the broader environment is inappropriate. Thus, a child might be inadequately socialized and conduct disordered at one point 
in time and subsequently become inappropriately socialized and socially maladjusted at a later time.

\section{IDENTIFICATION}

SMA has been defined as socialized aggression (subcultural delinquency or conduct disorder, group type). Several instruments are useful for identifying delinquency. Before briefly discussing these, however, it should be useful to point out an error that could easily be made in using delinquency as the operational term for SMA. Delinquency is, of course, a legal term-not an educational, psychological, or medical term-covering a diverse group of children and youth. Three basic distinctions are made within this population (Quay, 1965, 1987). The relationship of these three terms to socialization and DSM III-R diagnoses is presented in Table 1, along with some other frequently used terms.

TABLE 1

The Relationship of Socialization

To Diagnostic and Descriptive Labels

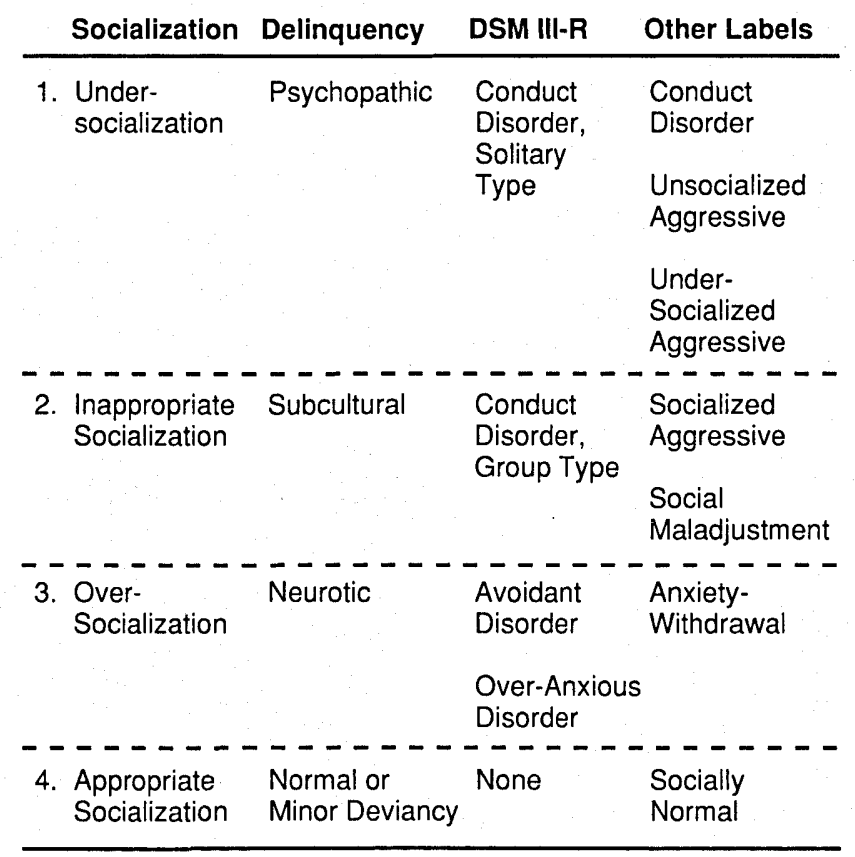

First, there is the psychopathic delinquent, characterized by active, antisocial aggressiveness, impulsivity, failure to learn from experience, defiance of authority, and a deficit in conscience. Psychopathic delinquents' lack of social development is often evident in behaviors such as lying, stealing, drinking, and sexual misconduct. The problems found in this group are generally believed to be the result of undersocialization or inadequate socialization.
Second, there is the subcultural delinquent. The subcultural delinquent has been socialized, but with an inappropriate or deviant set of values. Unlike psychopathic delinquents, they are extremely loyal to their peer group. Conscience is evident in this population, but only deviation from the standards or values of the peer group elicits guilt responses in them. Deviation from the norms of the mainstream culture, such as antisocial behavior, results in little, if any, sense of guilt. The subcultural delinquent is characterized by an emphasis on values for physical prowess, the ability to out-smart others, rebelliousness, and thrill seeking. This group is not generally considered emotionally disturbed but, rather, inappropriately socialized.

Third, there is the neurotic delinquent. This group is similar to other neurotics except for the antisocial behavior. It is often hypothesized that the antisocial behavior is motivated by feelings of guilt and a desire for punishment. Individuals in this group are often characterized as shy, self-conscious, hypersensitive, unhappy, guilty, and anxious. They are generally considered to be, at least in part, the product of oversocialization.

Considering that SMA has been defined as the second subtype (subcultural delinquency), we must be careful, when attempting to identify this group, not to simply look for evidence of, or tendencies toward, delinquency in general. Rather, we must attempt to differentiate between those identified as delinquent or potentially delinquent and diagnose only those who fit the socialized aggressive (subcultural delinquency) pattern as SMA. Further, once SMA has been diagnosed in a student, the diagnostic process cannot be terminated legitimately until the assessment process rules out the possibility that other qualifying conditions for SED are not also present. A number of instruments might be useful in making a diagnosis of SMA; these are summarized in Table 2 and discussed next.

\section{Behavior Assessment}

The Revised Behavior Problem Checklist (RBPC) was developed by Quay and Peterson (1983). It is a rating scale whose data are derived from an informant such as a teacher. The scale has several dimensions, one of which is socialized aggression. This instrument should be particularly useful because it also has dimensions for conduct disorder (under-socialized aggression) and anxietywithdrawal (neurotic or affective disorder), which should be helpful in differentiating the three subtypes of delinquency discussed previously. 
TABLE 2

Some Potentially Useful Instruments for Differentiating Conduct Disorder from Social Maladjustment

\begin{tabular}{|c|c|c|c|}
\hline Test & Authors & Data & Key Scales \\
\hline $\begin{array}{l}\text { Revised } \\
\text { Behavior } \\
\text { Problem } \\
\text { Checklist } \\
\text { (RBPC) }\end{array}$ & $\begin{array}{l}\text { Quay \& } \\
\text { Peterson } \\
(1983)\end{array}$ & Teacher & $\begin{array}{l}\text { Conduct Disorder } \\
\text { Socialized- } \\
\text { Aggression }\end{array}$ \\
\hline $\begin{array}{l}\text { Differential } \\
\text { Behavioral } \\
\text { Classification } \\
\text { (DBC) }\end{array}$ & $\begin{array}{l}\text { Quay \& } \\
\text { Parsons } \\
(1971)\end{array}$ & $\begin{array}{l}\text { Teacher } \\
\text { Social Worker } \\
\text { Student }\end{array}$ & $\begin{array}{l}\text { Conduct Disorder } \\
\text { Socialized- } \\
\text { Aggression }\end{array}$ \\
\hline $\begin{array}{l}\text { Child } \\
\text { Behavioral } \\
\text { Checklist } \\
\text { (CBCL) }\end{array}$ & $\begin{array}{l}\text { Achenbach } \\
\& \\
\text { Edelbrock } \\
(1981)\end{array}$ & $\begin{array}{l}\text { Parent } \\
\text { Teacher } \\
\text { Student } \\
\text { Psychologist }\end{array}$ & $\begin{array}{l}\text { Aggressive } \\
\text { Delinquent }\end{array}$ \\
\hline PIC & $\begin{array}{l}\text { Wirt et al. } \\
\text { (1977) }\end{array}$ & Parent & $\begin{array}{l}\text { Adjustment } \\
\text { Delinquency }\end{array}$ \\
\hline $\begin{array}{l}\text { Eysenck } \\
\text { Personality } \\
\text { Inventory } \\
\text { (EPI) }\end{array}$ & $\begin{array}{l}\text { Eysenck \& } \\
\text { Eysenck } \\
\text { (1975) }\end{array}$ & Student & $\begin{array}{l}\text { Psychoticism } \\
\text { Extroversion }\end{array}$ \\
\hline $\begin{array}{l}\text { Defining } \\
\text { Issues } \\
\text { Test }\end{array}$ & $\begin{array}{l}\text { Rest } \\
\text { (1979) }\end{array}$ & Student & $\begin{array}{l}\text { Moral Judgment } \\
\text { Anti-establishment }\end{array}$ \\
\hline
\end{tabular}

An earlier version of the Behavior Problem Checklist (BPC) by Quay and Peterson (1967) was used as part of a procedure for the differential behavioral classification of juvenile offenders, hereafter referred to as the DBC. This procedure has excellent potential for use in making differential diagnoses between conduct disorder (psychopathic delinquency) and SMA (subcultural delinquency). The DBC utilizes three instruments: the original BPC, which is completed by an informant (e.g., a teacher); a Life History instrument, which is completed by a social worker or other professional; and the Personal Opinion Test, completed by the youth to be classified. A composite score for each of four classification dimensions is obtained, and the youth is classified in the category for which the highest composite score is obtained.

There is also a procedure for determining the confidence level of the classification when two categories yield high and similar scores. In such cases one could argue that the youth has significant problems in both categories and should be given a dual diagnosis.

The second instrument-the Child Behavioral Checklist (CBCL), by Achenbach and Edelbrock (1981)-is also a rating scale. This is a more complex instrument than the $\mathrm{RBPC}$. The CBCL is divided into two versions, by age. The CBCL for ages 4-16 years should be the most useful in assessments of school-age children and youth. It is also scored by age and gender and has somewhat different problem dimensions according to age and gender. The CBCL usually is completed by a parent or parent surrogate.

The CBCL assessment also includes a Teacher Report Form, Youth Self-Report, and Direct Observation Form. The latter is also in a rating format, but the ratings are based on current observations rather than on knowledge gained from prior contact. This instrument has delinquency scales in its various formats, which appear to be based primarily upon the characteristics associated with socialized aggression or SMA. Like the RBPC, the CBCL has a number of other scales, such as aggressive (conduct disorder) and depressed (affective disorder), that should be useful for discriminating SMA from other problems involving antisocial behavior.

\section{Personality Assessment}

The Personality Inventory for Children (PIC), by Wirt, Lachar, Klinedinst, and Seat (1977) is similar in structure to the Minnesota Multiphasic Personality Inventory (MMPI), which often is used in the assessment of adults. The PIC uses a series of true-and-false questions that are answered by the child's or youth's parent or parent surrogate. Like the other measures already discussed, this one has a delinquency scale along with several other scales.

The delinquency scale appears to focus largely on the characteristics associated with socialized aggression. But the PIC may not be as useful as the other two instruments in differentiating SMA from conduct disorder. The PIC does not have a scale that is clearly directed at undersocialized aggression (conduct disorder). The scale that appears to come the closest in this regard is the Adjustment scale.

A second instrument that appears to be potentially useful is the Eysenck Personality Inventory (EPI) by Eysenck and Eysenck (1975). This instrument has both an adult and a junior form. Two of the EPI scales may be useful for differential diagnosis of SMA and conduct disorder. The Extroversion (E) and Psychoticism (P) scales are related to antisocial behavior. A high score on the $(\mathrm{P})$ scale is associated with social isolation and insensitivity to others; these are traits most likely to be found in the undersocialized (conduct disorder) persons. A high score on the (E) scale is associated with a predisposition to violate social norms. This trait is most likely to be found in inappropriately socialized (SMA) people. 


\section{Assessment of Moral Reasoning}

A potentially useful instrument for assessing sociomoral reasoning is the Defining Issues Test (DIT), by Rest (1979). The DIT is an objectively scored measure of moral reasoning based on a developmental model of moral reasoning (Kohlberg, 1969). Research (Jurkovic \& Prentice, 1977) has shown that psychopathic delinquents (under-socialized aggressive) have significantly greater deficits in moral reasoning than do subcultural or neurotic delinquents or normal controls. In fact, this research, using Kohlberg's interview method for assessing moral reasoning, found little difference in the level of moral reasoning in the latter three groups.

In a more recent study using the DIT, a multiple-choice measure of moral reasoning, McColgan, Rest, and Pruitt (1983) also found that the DIT could differentiate between normal and antisocial youths. But the DIT appears to be capable of making finer discriminations than the interview method. The DIT identified two different groups within the delinquent sample; both groups were deficit in moral reasoning ability, but one group had a much greater deficit than the other.

Whether this apparent ability to make finer discriminations would be helpful in trying to distinguish between conduct disorder and SMA is unclear. The antisocial sample used in this study consisted of unclassified, incarcerated delinquents. The authors do indirectly suggest that many of their subjects probably came from the subcultural delinquent group. It may have been this portion of the sample that the DIT identified whereas the interview method failed to do so. Assuming this to be the case, socially maladjusted people might be expected to score lower on the DIT than socially normal youths, and conduct disordered persons would score lower than those who are socially maladjusted.

Another potentially useful facet of the DIT is that it provides an anti-establishment score along with the score for moral reasoning. Because the subcultural delinquent group is characterized by deviant socialization and rebelliousness against mainstream authority, this subscore could prove to be useful in identifying SMA. But undersocialized aggressive individuals also frequently do not accept authority either. In short, the possible usefulness of this subscore in differential diagnosis remains to be demonstrated but appears to be worth investigation.

\section{Social History}

In addition to the use of various assessment instruments such as those described, an assessment-based diagnosis should be supported by a social history. The social history should attempt to confirm several life-space characteristics.

1. There should be confirmation that the student comes from a community or portion of a community that may include, but is not limited to, the family, that accepts as normal the antisocial behavior that the student exhibits.

2. There should be evidence that the student has strong allegiance to a deviant peer group based in the community.

3. There should be confirmation that the antisocial behavior the student exhibits is modeled, accepted, and supported by the deviant peer group.

4. There should be confirmation that the student engages in antisocial behavior in cooperation with other members of the deviant peer group.

\section{PROGRAMMING}

Program development should rest upon an hypothesis about the genesis of the problem the program is intended to address. The hypothesis that will underlie the program suggestions in this section is based upon an adaptation of Sutherland and Cressey's (1978) concept of differential association. A shortened and somewhat modified version of this concept is outlined as follows.

1. Delinquent behavior is learned.

2. Delinquent behavior is learned in interaction with others in a process of communication.

3. The principal part of learning delinquent behavior occurs within intimate personal groups.

4. An individual becomes delinquent because of an excess of socialization favorable to delinquency over socialization unfavorable to delinquency.

As discussed, the two major socialization influences on children and youth are the home and community. The home may socialize the child to attitudes, values, and behaviors that are consistent with delinquency. The families of delinquents also tend to promote or permit premature autonomy (Hirschi, 1969). Premature autonomy tends to reduce the influence of the home and to increase the influence of socialization agents outside the home, such as peers.

The general environmental conditions that appear to be most often associated with delinquency are those found in disorganized and disadvantaged communities (Glaser, 1965; Stumphauzer, Aiken, \& Veloz, 1977). This type of community offers little, if any, local support for community institutions and agencies, which often are operated by 
individuals who reside outside the community. This reduces the opportunities for contact with positive social models. Further, the communities often have a criminal population that is accorded considerable prestige and status within the community. This pattern increases the opportunities for contact with negative social models.

One important institution in any community is its public schools. A child whose family background is one that holds little value for education and accords little respect for teachers is highly predisposed to underachievement. Underachieving students have lost a major source of accomplishment within the school culture, which in turn may block their access to other, nonacademic sources of accomplishment. One outcome of loss of access to legitimate sources of accomplishment within the school culture is social isolation by more successful students. This isolation often promotes association and friendship formation within delinquency-prone, peer subcultures. The important role of friendships, within a deviant peer group, to delinquency has been documented by Giordano, Cernkovich, and Pugh (1986).

Loss of access to legitimate sources of accomplishment at school is somewhat analogous to the tendency toward premature autonomy from the family, mentioned earlier. Both of these events contribute to a significant loss of appropriate socialization experiences from the socially normal peer culture and promote affiliation with deviant peer subcultures. This association promotes differential exposure to inappropriate socialization experiences and development of a pattern of socially supported deviant behavior.

The etiology suggested here indicates that preventive or intervention efforts, or both, should be ecological in their approach. Both the family and the community, which includes the public schools, should be involved in any comprehensive effort. Such a broad-based ecological intervention is far too complex to be undertaken by a school-based program alone. Educational institutions are a critical component in the program, but the program has to entail a joint and coordinated effort involving many social institutions. Discussion of such a comprehensive ecological intervention is beyond the scope of this article. Therefore, the discussion is limited to some of the things that may be possible for a school-based program to undertake as an independent effort. These components are outlined in Figure 2.

\section{Prevention}

One approach to dealing with SMA is programming for prevention. From the school's perspective the pattern most frequently seen involves early academic failure, classroom misconduct, truancy, and dropping out of school. The first objective for a school-based program should be to prevent the early academic failure that precedes most classroom misconduct in the SMA population. These two variables, in combination with the lack of value for education often found in the student's home background, contribute to development of an intense dislike for school and teachers.

The net effect of this sequence is a loss of access to legitimate sources of accomplishment within the school setting. Once access to legitimate sources of accomplishment is lost, the school's potential for influence is greatly reduced and the potential influence of the peer group is enhanced. Because the student has become a failure in the eyes of the successful students and is socially rejected by them, the less desirable portion of the peer group gains most of the potential for filling this "influence vacuum."

Remediation of academic difficulties can be undertaken at almost any point in a student's school career. Because the pattern of school failure often begins as early as the primary grades, however, the earlier the problem is recognized and addressed, the more likely it is that the effort will be successful. One approach to remediation that has been shown to be successful is direct instruction of deficit skills (Becker \& Carnine, 1981; Becker \& Engelmann, 1978; Center, 1989a; Engelmann, 1969; Stephens, Hartman, \& Lucas, 1982).

Besides academic skill enhancement, most students experiencing academic failure need to develop achievement motivation. Achievement motivation should be included in any program to modify a pattern of school failure in students from disadvantaged backgrounds (DeCharms, 1976).

In addition to early efforts to prevent chronic school failure, the school should attempt to create an atmosphere that counters influences that tend to alienate the student from school (Sutherland \& Cressey, 1978). First, the school should establish a positive discipline rather than an aversive school environment. This means using an authoritative instead of an authoritarian approach to discipline (Baumrind, 1968). The difference between these two approaches is basically the difference between control through reason and reward versus control through threat and punishment.

Second, the school should teach these students the coping skills needed to be successful in the school setting. Programming in this area can include classroom skills, e.g., learning strategies; interpersonal skills, e.g., negotiation; task skills, e.g., neatness; and self-related skills, e.g., accepting responsibility (Center, 1989a; Stephens, 1978; 


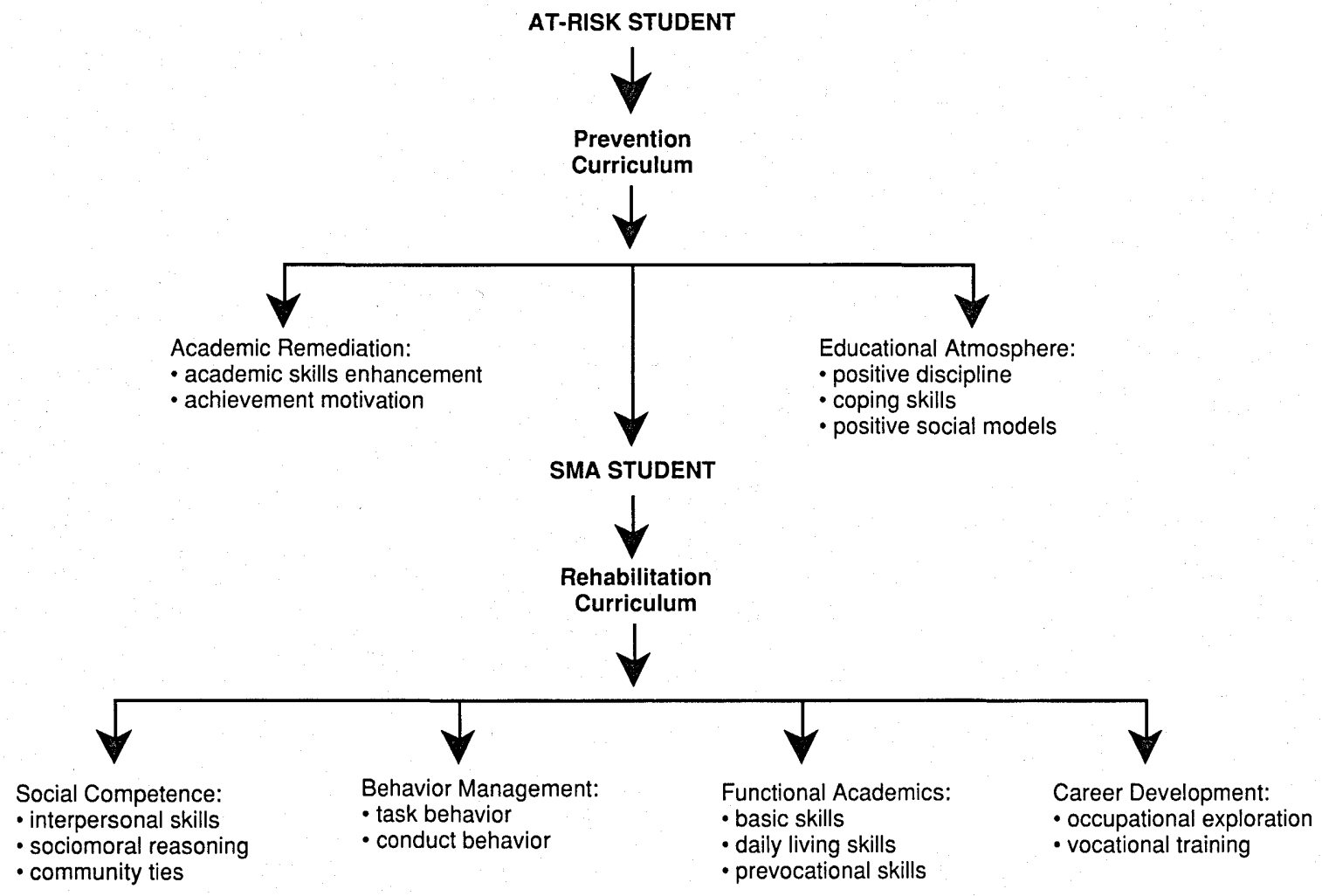

FIGURE 2

Curriculum Components for a Preventive Program and a Rehabilitative Program

Walker, et al., 1983).

Third, the school should attempt to enhance the prestige value or social status of positive social models that the student may encounter. These models should include individuals who may be encountered in the community, who have made successful adjustments and make positive contributions to the community. Some of the most likely candidates include individuals in various trades (e.g., plumbers); various public service positions (e.g., firemen); various business occupations (e.g., store managers and clerks), and so on.

Emphasis should be on the community roles these individuals fill, the positive function of these roles for the community, and the benefits that accrue to the individuals filling these roles. The program also can be viewed as part of the initial stage of career education-career awareness (Center, 1989a; Kokaska \& Brolin, 1985).

\section{Rehabilitation}

For efforts that begin later in a student's school career and after prevention of SMA is no longer a reasonable objective, a rehabilitation program may be the best approach (Romig, 1978). The program should focus on teaching skills (Carhuff \& Berenson, 1976; Phillips, Phillips, Fixsen, \& Wolf, 1974) to rehabilitate the SMA student. Skill areas that should be addressed in the rehabilitation program include social competence, functional academic skills, and career and vocational skills. The proposed treatment program components are summarized in Figure 2 and are discussed next.

\section{Social Competence}

Four areas are suggested for a program to rehabilitate social behavior and establish social competence for the mainstream culture. The first of these includes what are often referred to as social or interpersonal skills. Behavioral skills encompass the broad areas of positive interaction skills, communication skills, and cooperation and sharing skills (Center, 1989a). Three descriptions of teaching sequences for establishing these skills can be found in Center (1989a), Goldstein (1988), and Phillips et 
al. (1974). Sarason and Ganzer $(1969,1973)$ have developed training programs that specifically target interpersonal problem-solving deficits in delinquents; these should prove useful in developing individualized programs in this area.

A potentially useful instrument for identifying social skill deficits in delinquents is the Adolescent Problems Inventory (API), by Freedman, Rosenthal, Donahoe, Schlundt, and McFall (1978). This criterion-referenced inventory consists of 44 behavioral role-playing and problem-solving items. The API was shown to be a reliable instrument that was able to discriminate between delinquent and non-delinquent adolescents on the basis of their social competence in dealing with everyday problem situations. The API also was shown to differentiate two subpopulations within the delinquent population. In terms of the categories used in discussing delinquency in this article, these two subpopulations probably could be described as the psychopathic (conduct disorder) and subcultural (SMA) delinquent groups. The API and the skill deficits it can identify should be a valuable aid for designing individualized social skill programs.

Second, there is the often neglected but important cognitive aspect to social competence (Center, 1989a; Goldstein \& Glick, 1987). This component is often called sociomoral reasoning. McColgan, Rest, and Pruitt (1983) suggest that adequate development in this area is a necessary precursor for conformity to social rules. The ability to understand and appreciate the fairness of societal rules is the basis for the internal motivation to comply with them. As discussed earlier, the SMA population appears to have mild deficits in sociomoral reasoning.

Arbuthnot and Gordon (1986) evaluated the effects of a sociomoral intervention program on delinquents. They found significant improvements on measures of sociomoral reasoning, disciplinary referrals, police/court contacts, tardiness, and grades following intervention. A one-year follow-up showed that all of the above improvements had been maintained except for police/court contacts, which could not be evaluated because neither the experimental group nor the control group had any such contacts during the follow-up period. In addition, a significant improvement for the control group in absenteeism was found during the follow-up evaluatuion.

Suggestions for programming in this area can be found in Center (1989a), including a discussion of Selman's (1980) work extending Kohlberg's work on moral reasoning to four domains of interpersonal or social reasoning, and in Goldstein (1988) and Goldstein and Glick (1987).

Third, any discussion of programming to enhance social competence in the SMA population, in which the broad social environment is believed to play an important role, would be incomplete without some attention to community ties. As noted earlier, intervention in the community itself is not within the school's power. Nevertheless, a school program can attempt to influence a student's perception and understanding of the community and its institutions.

One ecological approach to treating SED students, ReEd (Hobbs, 1966, 1967), includes such a component. This strategy attempts to develop community ties, largely through field trips to various public agencies within the community (e.g., fire, police, health, and employment agencies) and to various private organizations (e.g., labor, political, fraternal, and business organizations). The program is designed to help the student understand and appreciate the role and function of these agencies and organizations for the community and their potential, if not current importance, for the student. The program to develop community ties also may include participation in organizations such as community athletic programs, continuing education programs, libraries, volunteer service organizations, and the like.

Another potentially useful approach related to developing an understanding of the community is legal education (Turner \& Parisi, 1984). In this program students are helped to learn about the legal and judicial system through discussion and role-play activities. Activities from this program could be integrated with police, court, jail, and even legislative field trips.

\section{Behavioral Management}

A program to rehabilitate delinquents should incorporate a behavior management component to control inappropriate social behavior and to reinforce and motivate participation in the instructional program. Both task behavior and conduct behavior should be included. The best behavior management system for these purposes is a structured management program based on behavioral principles (Center, 1989a; Center \& McKittrick, 1987; Kazdin, 1977). An important part of such a program is a levels system (Bauer \& Shea, 1988) to facilitate weaning the student from the imposed structure, increase delay of gratification, enhance self-evaluation skills, and promote control by natural reinforcers.

\section{Functional Academic Skills}

An older student who has suffered from chronic school failure is not a good candidate for a traditional academic curriculum. An alternative curriculum for these students may be needed. The curriculum should focus on teaching the students skills they will be likely to perceive as personally relevant. 
Traditional academic skills should be limited to those not yet mastered that are essential for good community functioning. Basic skills in reading and math should be taught using functional and real-life materials whenever possible. One way to accomplish this is to use a career education model to develop a curriculum.

A model that could be used or adapted for use is the Life-Centered Career Education curriculum (Brolin, 1978) or other similar curricula (Bender \& Valletutti, 1982; Falvey, 1986; Wilcox \& Bellamy, 1987). Whether one of the above curricula is used or adapted for use or a curriculum is created locally, emphasis should be on the use of activities that teach necessary academic skills while teaching daily living skills such as reading want ads, managing money, and so forth.

The earlier discussion on programming to develop social competence could be substituted for the social studies component found in the traditional curriculum. The component in social competence that has the clearest relationship to a traditional social studies curriculum is the one dealing with developing community ties. The traditional science curriculum might be replaced by curricula dealing with health, hygiene, sexuality, and drug and alcohol abuse. It is worth repeating that whatever is done should have a functional emphasis and be perceived as relevant by the students.

A more drastic alteration of the instructional program may be necessary for some students. Their instruction may have to be based on a bookless approach (Silberberg \& Silberberg, 1969). In this approach instruction is undertaken through the use of audiovisual materials, discussion, and various aids such as calculators and audiotapes of books, magazines, newspapers, and the like.

Some students may have the potential for success in a more traditional academic curriculum but are not fulfilling that potential. For those students a functional curriculum, including prevocational skills, that is perceived as relevant may in time spark their interest in learning to a sufficient degree that they can be shifted back into a traditional curriculum.

\section{Career and Vocational Skills}

Certain career and vocationally related skills should be part of the social competence and functional academics programs. Interviewing for a job, accepting supervision, and accepting criticism of work are examples of social skills applied in an occupational context. Reading want ads, filling out job applications, and computing pay and deductions are other basic academic skills applied in an occupational context. The type of program being discussed is an integrated one with common threads running through all components.

The component discussed here should be concerned largely with developing awareness of occupations, including site visits and occupational exploration in areas of interest, along with opportunities for concrete experiences related to the occupation. It also should include occupational selection and decision-making skills. Development of occupational decision-making skills should be preceded by a good vocational assessment, including work and performance samples.

Because occupational selection and decision making should lead to vocational preparation, occupational exploration should include a number of occupations for which vocational training is a real possibility. During the selection and decision-making process, emphasis should be placed on realistic possibilities for training. Every effort should be made to make those possibilities numerous and diverse. The Brolin (1978) curriculum model mentioned earlier addresses some of these components, as does a curriculum developed by Weisgerber (1989).

Actual vocational training and job placement with support are important components in the rehabilitation program. In a study of the effects of an intervention in which employment was a critical feature, Mills and Walter (1979) found a significant reduction in delinquency. In this study there were 76 delinquents, with a mean arrest rate of 3.85. These subjects were divided between a control group and an experimental group. The intervention lasted approximately 18 months and was similar to what is called supported employment (Center, 1989a). Criteria for success in the program were:

1. No further arrests or institutionalization.

2. Remain on a job a minimum of three months or stay in school and, if a drop-out, go back to school or get further vocational training.

Against these criteria, approximately $85 \%$ of the treatment group was judged to be successful, compared to approximately $13.5 \%$ of the control group.

One final comment should be made concerning programming. Placing under-socialized aggressive (conduct disorder) students into programs with socialized aggressive (SMA) students probably is not desirable. As mentioned earlier, and pointed out in Center (1989b), the conductdisordered student is at risk for becoming socially maladjusted if brought into contact with the socialization influence of a deviant peer group. For this reason, differentiating these two groups and not exposing the under-socialized, conduct-disordered student to in- 
appropriate socialization are important factors. Although the service needs of both groups involve programming directed at socialization, co-placement of members of the two groups runs a considerable risk of being counterproductive for the conduct-disordered student.

\section{REFERENCES}

Achenbach, T., \& Edelbrock, C. (1981). Child Behavior checklist. Burlington, VT: University Associates in Psychiatry.

American Psychiatric Association. (1987). Diagnostic and statistical manual of mental disorders (3rd ed.). Washington, DC: Author.

Arbuthnot, J., \& Gordon, D. (1986). Behavioral and cognitive effects of a moral reasoning development intervention for high-risk behaviordisordered adolescents. Journal of Consulting \& Clinical Psychology, 55, 208-216.

Bauer, A., \& Shea, T. (1988). Structuring classrooms through levels systems. Focus on Exceptional Children, 2l(3).

Baumrind, D. (1968). Authoritarian vs. authoritative parental control. Adolescence, 2, 255-272.

Becker, W., \& Carnine, D. (1981). Direct instruction: A behavior theory model for comprehensive educational intervention with the disadvantaged. In S. Bijou \& R. Ruiz (Eds.), Behavior modification: Contributions to education. Hillsdale, NJ: Lawrence Erlbaum.

Becker, W., \& Engelmann, S. (1978). Systems for basic instruction: Theory and applications. In A. Cantania \& T. Brigham (Eds.), Handbook for applied behavior analysis: Social and instructional processes. New York: Irvington.
Bender, M., \& Valletutti, P. (1982). Teaching functional academics: A curriculum guide for adolescents and adults with learning problems. Baltimore: University Park Press.

Bleuler, M. (1974). The offsprings of schizophrenics. Schizophrenia Bulletin, 8, 93-107.

Bower, E. (1981). Early identification of emotionally handicapped children in school (3rd ed.). Springfield, IL: Charles Thomas.

Bower, E. (1982). Defining emotional disturbance: Public policy and research. Psychology in the Schools, 19, 55-60.

Brolin, D. (1978). Life-centered career education: A competency based approach. Reston, VA: Council for Exceptional Children.

Carhuff, R., \& Berenson, B. (1976). Teaching as treatment. Amherst, MA: HRD Press.

Center D. (1989a). Curriculum and teaching strategies for students with behavioral disorders. Englewood Cliffs, NJ: Prentice-Hall.

Center D. (1989b). Social maladjustment: An interpretation. Paper presented at annual conference of Council for Exceptional Children, San Francisco.

Center D., \& Eden, A. (1989). Variables affecting under-identification of students with behavioral disorders: 2. National Forum of Special Education.

Center D., \& McKittrick, S. (1987). Disciplinary removal of special education students. Focus on Exceptional Children, 20(2), 1-10.

Clarizio, H. (1987). Differentiating emotionally impaired from socially maladjusted students. Psychology in the Schools, 24, 237-243.

Council for Children with Behavioral Disorders (1987). Position paper on definition and identification of students with behavioral disorders. Behavioral Disorders, 13, 9-19.

DeCharms, R. (1976). Enhancing motivation: Change in the classroom. New York: Irvington.

\section{Teaching Students with Behavior Disorders}

\section{Patricia A. Gallagher \\ University of Kansas}

This excellent revision gives current strategies and techniques that really work. It is chock-full of activities for classroom instruction that will make your class a joy for your students. Many examples, photos, illustrations, forms, and vignettes make this book engaging and contemporary.

Teaching Students with Behavior Disorders has been updated and expanded to include the latest practical tools for working with troubled children.

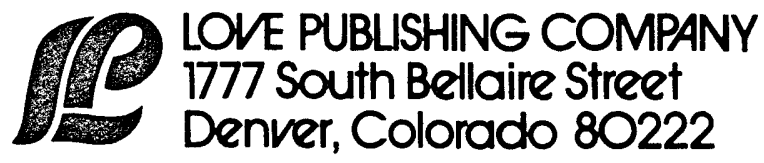

\section{CONDDNIS}

1 Troubled Youth: An Overview

\section{Part I Planning}

2 Advanced Organization

3 Educational Diagnosis

\section{Part II Curriculum}

4 Curriculum: Basic Considerations

5 Curriculum: Special Considerations

6 Instructional Techniques

\section{Part III Management and Organization}

7 Management: Overview

8 Management: Psychoeducational Techniques

9 Management: Behavior Modification Techniques

10 Scheduling

\section{Part IV Communication}

11 Communication with Significant Adults

12 Communication with Future Employers 
Engelmann, S. (1969). Preventing failure in the primary grades. New York: Simon \& Schuster.

Eysenck, H., \& Eysenck, S. (1975). Manual for the Eysenck Personality Inventory. San Diego: Educational and Industrial Testing Service.

Falvey, M. (1986). Community-based curriculum. Baltimore: Paul H. Brookes.

Freedman, B., Rosenthal, L., Donahoe, C., Schlundt, D., \& McFall, R. (1978). A social-behavioral analysis of skill deficits in delinquent and nondelinquent adolescent boys. Journal of Consulting \& Clinical Psychology, 46, 1448-1462.

Giordano, P., Cernkovich, S., \& Pugh, M. (1986). Friendship and delinquency. American Journal of Sociology, 91, 1170-1202.

Glaser, D. (1965). Social disorganization and delinquent subcultures. In H. Quay (Ed.), Juvenile delinquency.Princeton, NJ: Van Nostrand.

Goldstein, A. (1988). The Prepare curriculum: Teaching prosocial competencies. Champaign, IL: Research Press.

Goldstein, A., \& Glick, B. (1987). Aggression replacement training. Champaign, IL: Research Press.

Hirschi, T. (1969). Causes of delinquency. Berkeley, CA: University of California Press.

Hobbs, N. (1966). Helping disturbed children: Psychological and ecological strategies. American Psychologist, 21, 1105-1115.

Hobbs, N. (1967). The re-education of emotionally disturbed children. In E. Bowen \& W. Hollister (Eds.), Behavioral science frontiers. New York: Wiley.

Jurkovic, G., \& Prentice, N. (1977). Relation of moral and cognitive development to dimensions of juvenile delinquency. Journal of Abnormal Psychology, 86, 414-420.

Kazdin, A. (1977). The token economy: A review and evaluation. New York: Plenum.

Kelly, E. (1986). The differential problem sorter: Rationales, procedures, and statistical/clinical values. Unpublished manuscript, University of Nevada at Las Vegas.

Kohlberg, L. (1969). The child as moral philosopher. In D.A. Goslin (Ed.), Handbook of socialization theory and research. Skokie, IL: Rand McNally.

Kokaska, C., \& Brolin, D. (1985). Career education for handicapped individuals (2nd ed.). Columbus, $\mathrm{OH}$ : Merrill.

Kupersmidt, J., \& Patterson, C. (1987). Interim report to the Charlottesville public schools on children at risk. Unpublished manuscript, University of Virginia, Charlottesville, VA: discussed in J. Kauffman (1989), Characteristic's of children's hehavioral disorders (4th ed.), Columbus, $\mathrm{OH}$ : Merrill.

McColgan, E., Rest, J., \& Pruitt, D. (1983). Moral judgment and antisocial behavior in early adolescence. Journal of Applied Developmental Psychology, 4. 189-199.

Mednick, A., \& Hutchings, M. (1978). Genetic and psychophysiological factors in asocial behavior. Journal of Child Psychiatry, 209-223

Mednick, S., Schulsinger, H., \& Schulsinger, F. (1975). Schizophrenia in children of schizophrenic mothers. In A. Davids (Ed.), Child personality and psychopathology (Vol. 2). New York: Wiley.

Mills, C.. \& Walker, T. (1979). Reducing juvenile delinquency: A behavioral-employment intervention program. In J. Stumphauzer (Ed.), Progress in behavior therapy with delinquents. Springfield, IL: Charles Thomas.

Phillips, E.L., Phillips, E.A., Fixsen, D., \& Wolf, M. (1974). The teaching family handbook. Lawrence: University of Kansas Printing
Service.

Quay, H. (1965). Personality and delinquency. In H. Quay (Ed.), Juvenile delinquency. Princeton, NJ: Van Nostrand.

Quay, H. (1987). Patterns of delinquent behavior. In H. Quay (Ed.), Handbook of juvenile delinquency. New York: Wiley.

Quay, H., \& Parsons, L. (1971). The differential behavioral classification of the juvenile offender (2nd ed.). Washington, DC: U.S. Bureau of Prisons.

Quay, H., \& Peterson, D. (1967). Manual for the Behavior Problem Checklist. Unpublished.

Quay, H., \& Peterson, D. (1983). Revised behavior problem checklist. Coral Gables, FL: University of Miami.

Rest, J. (1979). Revised manual for the Defining Issues Test. Minneapolis: University of Minnesota.

Romig, D. (1978). Justice for our children. Lexington, MA: Lexington Books.

Sarason, I., \& Ganzer, V. (1969). Developing appropriate social behaviors of juvenile delinquents. In J. Krumboltz \& C. Thoresen (Eds.), Behavior counseling cases and techniques. New York: Holt, Rinehart \& Winston.

Sarason, I., \& Ganzer, V. (1973). Modeling and group discussion in the rehabilitation of juvenile delinquents. Journal of Counseling Psychology, 20, 442-449.

Selman, R. (1980). The growth of interpersonal understanding. New York: Academic Press.

Silberberg, N., \& Silberberg, M. (1969). The bookless curriculum: An educational alternative. Journal of Learning Disabilities, 2 , 302-307.

Slenkovich, J. (1983). P.L. $94-142$ as applied to DSM III diagnoses: An analysis of DSM III diagnoses vis-a-vis special education law. Cupertino, CA: Kinghorn Press.

Stephens, T. (1978). Social skills in the classroom. Columbus, OH: Cedars Press.

Stephens, T., Hartman, A., \& Lucas, V. (1982). Teaching children basic skills: A curriculum handbook. Columbus, $\mathrm{OH}$ : Merrill.

Stumphauzer, J., Aiken, T., \& Veloz, E. (1977). East side story: Behavioral analysis of a high juvenile crime community. Behavioral Disorders, 2, 76-84.

Sutherland, E., \& Cressey, D. (1978). Criminology (10th ed.). New York: Lippincott.

Thomas, A., Chess, S., \& Birch, H. (1968). Temperament and hehavioral disorders in children. New York: New York University Press.

Turner, M., \& Parisi, L. (1984). Law in the classroom: Activities and resources (rev.) Boulder, CO: ERIC Clearinghouse for Social Studies/Social Science Education.

Walker, H., McConnell, S., Holmes, D., Todis, B., Walker, J., \& Golden, N. (1983). The Walker social skills curriculum: The ACCEPTS program. Austin, TX: Pro-Ed.

Weisgerber, R. (1989). Social competence and employability skills (urriculum. Rockville, MD: Aspen.

Wilcox, B., \& Bellamy, G. (1987). The activities catalog: An alternative curriculum for youth and adults with severe disabilities. Baltimore: Paul H. Brookes.

Wirt, R., Lachar, D. Klinedinst, J., \& Seat, P. (1977). Multidimensional description of child personality: A manual for the Personality Inventory for Children. Los Angeles: Western Psychological Services. 